\title{
The effects of interleukin-8 on airway smooth muscle contraction in cystic fibrosis
}

Vasanthi Govindarajuํㄹ, Marie-Claire Michoud ${ }^{1}$, Pasquale Ferraro², Janine Arkinson ${ }^{1}$, Katherine Safka ${ }^{1}$, Hector Valderrama-Carvajal and James G Martin*1

Address: ${ }^{1}$ Seymour Heisler Laboratory of the Montreal Chest Institute Research Center and Meakins Christie Laboratories, McGill University, Montreal, Quebec, Canada and 2University of Montreal Hospital Center, Montreal, Quebec, Canada

Email: Vasanthi Govindaraju - Vasanthi.govindaraju@mcGill.ca; Marie-Claire Michoud - marie-claire.michoud@mcgill.ca; Pasquale Ferraro - pasquale.ferraro@umontreal.ca; Janine Arkinson - janinearkinson@ hotmail.com; Katherine Safka - ksafka@po-box.mcgill.ca; Hector Valderrama-Carvajal - hfvc@yahoo.com; James G Martin* - James.martin@mcGill.ca

* Corresponding author

Published: I December 2008

Respiratory Research 2008, 9:76 doi:10.1 |86/| 465-992I-9-76
Received: 16 July 2008

Accepted: I December 2008

This article is available from: http://respiratory-research.com/content/9/1/76

(C) 2008 Govindaraju et al; licensee BioMed Central Ltd.

This is an Open Access article distributed under the terms of the Creative Commons Attribution License (http://creativecommons.org/licenses/by/2.0), which permits unrestricted use, distribution, and reproduction in any medium, provided the original work is properly cited.

\begin{abstract}
Background: Many cystic fibrosis (CF) patients display airway hyperresponsiveness and have symptoms of asthma such as cough, wheezing and reversible airway obstruction. Chronic airway bacterial colonization, associated with neutrophilic inflammation and high levels of interleukin-8 (IL8 ) is also a common occurrence in these patients. The aim of this work was to determine the responsiveness of airway smooth muscle to IL-8 in CF patients compared to non-CF individuals.
\end{abstract}

Methods: Experiments were conducted on cultured ASM cells harvested from subjects with and without CF (control subjects). Cells from the $2^{\text {nd }}$ to $5^{\text {th }}$ passage were studied. Expression of the IL8 receptors CXCRI and CXCR2 was assessed by flow cytometry. The cell response to IL- 8 was determined by measuring intracellular calcium concentration $\left(\left[\mathrm{Ca}^{2+}\right]_{\mathrm{i}}\right)$, cell contraction, migration and proliferation.

Results: The IL-8 receptors CXCRI and CXCR2 were expressed in both non-CF and CF ASM cells to a comparable extent. IL-8 (I00 nM) induced a peak $\mathrm{Ca}^{2+}$ release that was higher in control than in CF cells: $228 \pm 7$ versus $198 \pm 10 \mathrm{nM}(\mathrm{p}<0.05)$. IL-8 induced contraction was greater in $\mathrm{CF}$ cells compared to control. Furthermore, IL-8 exposure resulted in greater phosphorylation of myosin light chain $\left(\mathrm{MLC}_{20}\right)$ in CF than in control cells. In addition, $M L C_{20}$ expression was also increased in CF cells. Exposure to IL-8 induced migration and proliferation of both groups of ASM cells but was not different between $\mathrm{CF}$ and non-CF cells.

Conclusion: ASM cells of CF patients are more contractile to IL-8 than non-CF ASM cells. This enhanced contractility may be due to an increase in the amount of contractile protein $M L C_{20}$. Higher expression of $\mathrm{MLC}_{20}$ by CF cells could contribute to airway hyperresponsiveness to IL-8 in CF patients. 


\section{Background}

Cystic fibrosis (CF) is a genetic disease caused by defective $\mathrm{Cl}^{-}$secretion and enhanced $\mathrm{Na}^{+}$absorption across the airway epithelium [1]. The airways become infected with $P$. aeruginosa [2], S. aureus, $H$. influenzae, and respiratory syncytial virus [3-5]. Chronic bacterial infections and inflammation of the lung are the main causes of morbidity and mortality in CF patients [6]. With increasing age, CF patients develop airway obstruction and many of these patients also suffer from airway hyperresponsiveness and asthma-like symptoms [7,8]. Furthermore, Tiddens et al [9] have shown that airway remodeling similar to that of asthma affects CF airways, including changes in airway smooth muscle. In addition, in vivo studies with inhalation of bronchodilators improve the symptoms associated with bronchial responsiveness in CF patients indicating the presence of an asthma-like syndrome [10-12]. These findings suggest that the bronchial responsiveness observed in CF may be related to an increase in airway smooth muscle (ASM) contraction.

Many inflammatory cytokines are produced in the airways in CF patients [13]. Several studies have documented increased levels of interleukin-8 (IL-8; CXCL8) in bronchoalveolar lavage fluid and sputum and increased expression of IL-8 by bronchial glands of patients with CF [14-16]. In CF affected lungs, IL-8 is produced by neutrophils, airway epithelial cells, macrophages, and monocytes [17]. IL-8 binds to the G-protein coupled receptors CXCR1 and CXCR2 [18]. It acts as a chemotactic agent for neutrophils, T lymphocytes [19], basophils [20], NK cells and melanocytes [21]. It has also been shown that IL- 8 stimulates the proliferation and migration of rat vascular smooth muscle [22,23]. IL-8 inhalation provokes bronchoconstriction in guinea pigs in vivo [24]. As IL-8 is increased in the airways of CF patients and its action is not restricted to immune effector cells, it is possible that IL-8 may be involved in the airway hyperresponsiveness of CF by increasing smooth muscle contraction. Consistent with this hypothesis, we have demonstrated that ASM from healthy individuals expresses CXCR1 and CXCR2 and that IL-8 increases intracellular $\left[\mathrm{Ca}^{2+}\right]$ and triggers contraction [25]. Therefore, we hypothesized that, given the prolonged exposure of CF ASM to IL-8 in vivo, IL- 8 may evoke different contractile responses of ASM cells in CF. Thus we investigated the effects of IL-8 on the release of intracellular $\mathrm{Ca}^{2+}$ by ASM and on the contraction of ASM from CFaffected subjects and compared our findings to those of cells from CF non-affected subjects. We also examined the expression of CXCRs and the effects of IL- 8 on cellular migration and on ASM cell proliferation in both control and CF-affected subjects.

\section{Materials and methods Cell cultures}

Fragments of lobar bronchi were obtained from donors and recipients from lung transplants. The tissue was cut into small pieces of about $5 \mathrm{~mm} \times 5 \mathrm{~mm}$ and digested for $90 \mathrm{~min}$ at $37^{\circ} \mathrm{C}$ in Hanks balanced salt solution (HBSS) containing in mM: $\mathrm{KCl} 5, \mathrm{KH}_{2} \mathrm{PO}_{4} 0.3, \mathrm{NaCl} 138, \mathrm{NaHCO}_{3}$ $4, \mathrm{Na}_{2} \mathrm{HPO}_{4} 5.6$ to which collagenase type IV $(0.4 \mathrm{mg} / \mathrm{ml})$, soybean trypsin inhibitor $(1 \mathrm{mg} / \mathrm{ml})$ and elastase type IV $(0.38 \mathrm{mg} / \mathrm{ml})$ had been added. The dissociated cells were collected by filtration through $125 \mu \mathrm{m}$ Nytex mesh and the resulting suspension collected by centrifugation. The pellet was then reconstituted in growth medium (DMEM-Ham's F12 medium supplemented with 10\% fetal bovine serum, penicillin 10000 unit/ml, streptomycin $10 \mathrm{mg} / \mathrm{ml}$, and amphotericin $25 \mu \mathrm{g} / \mathrm{ml}$ ) and plated in $25-\mathrm{cm}^{2}$ flasks. ASM cells from CF subjects were isolated and cultured using a modification of the technique described by Randell et al [26] to avoid contamination. Briefly, small pieces of tissue were incubated for 20 minutes in cold Hanks buffer containing $0.5 \mathrm{mg} / \mathrm{ml}$ dithiothreitol and $10 \mu \mathrm{l} / \mathrm{ml}$ of Dnase type I, then placed in a cell dissociation medium HBSS containing: $0.4 \mathrm{mg} / \mathrm{ml}$ collagenase type IV, $1 \mathrm{mg} / \mathrm{ml}$ soybean trypsin inhibitor and $0.38 \mathrm{mg} / \mathrm{ml}$ elastase (type IV), penicillin $(100 \mathrm{U} / \mathrm{ml})$, streptomycin $(100 \mu \mathrm{g} / \mathrm{ml})$, ceftazidime $(100 \mu \mathrm{l} / \mathrm{ml})$, ciprofloxacin $(20 \mu \mathrm{l} / \mathrm{ml})$, colistin $(5 \mu \mathrm{g} / \mathrm{ml})$, tobramycin $(80 \mu \mathrm{g} / \mathrm{ml})$ and gentamycin: $(50 \mu \mathrm{g} / \mathrm{ml}$. The tissue was digested for 90 minutes at $37^{\circ} \mathrm{C}$ and the resulting cell suspension filtered and plated as described above. The same antibiotics were added to the culture medium for 4872 hours. ASM cells in primary cultures were identified by immunostaining for smooth muscle cell specific $\alpha$-actin, and Western blotting for myosin light chain kinase and calponin.

Confluent cells were detached with $0.025 \%$ trypsin solution containing $0.02 \%$ ethylenediaminetetraacetic acid (EDTA) and grown on $25 \mathrm{~mm}$ diameter glass coverslips for single cell imaging of $\mathrm{Ca}^{2+}$ transients, contraction studies and on 6 well culture dishes for flow cytometry, protein extraction, and chemotaxis assays.

\section{Contraction studies}

ASM cells from CF and non CF individuals were grown for 4 days, in parallel, on glass slides covered with homologous cell substrate as previously described [27]. The glass slides were placed in a Leiden chamber where the temperature was maintained at $37 \pm 0.5^{\circ} \mathrm{C}$ using a temperature controller (model TC-102; Medical System Corp). The cells were visualized using an inverted microscope with $20 \times$ magnification using Nomarski optics. A CCD camera (Hamamatsu C2400) was used to acquire and record images (Photon Technology International Inc, Princeton, NJ). Images were taken before and 10 minutes after the 
addition of IL-8 or phosphate buffered saline (PBS) as a vehicle for IL-8. Images were digitized and analyzed with the Scion software (National Institutes of Health, Bethesda, MD). The length of the cell was measured along its long axis by an observer blinded to the treatment. Contraction was expressed as the percentage decrease in cell length from the initial value.

\section{Flow Cytometry}

ASM cells were incubated with fluorescent labeled antibodies to CXCR1 and CXR2. The cells were fixed and analyzed by flow cytometry (FACScalibur) with commercial software to determine the levels of surface expression of CXCR1 and CXCR2.

\section{Measurement of intracellular $\mathbf{C a}^{2+}$}

Cytosolic $\mathrm{Ca}^{2+}$ was measured using Fura-2 and dual wavelength microfluorimetry. in single cells by imaging a group of 10-15 cells with a CCD camera (Photon Technology Inc, Princeton, NJ) at a single emission wavelength (510 nm) with double excitatory wavelengths (345 and $380 \mathrm{~nm}$ ) as previously described [28].

\section{Protein extraction and immunoblotting}

Expression and phosphorylation of the regulatory myosin light chain $\left(\mathrm{MLC}_{20}\right)$ were quantified by immunoblotting. Proteins were extracted from IL- 8 or vehicle stimulated cells. Blots were developed by chemiluminescence and the signals were acquired with an image analyser. Signals were analyzed by densitometry using commercial software and Imager (Fluorochem ${ }^{\mathrm{TM}}$, Flowgen Bioscience Limited, Nottingham, U.K).

\section{Chemotaxis assay}

Chemotaxis assays were performed using a modified Boyden chamber (Neuroprobe, Cabin John, MD). The number of migrated cells following treatments was expressed as a multiple of the value obtained with vehicle treated cells studied on the same day.

\section{Cell proliferation assay}

ASM cells from CF and control subjects were seeded onto six well plates at a density of $3 \times 10^{4}$ cells per well in DMEM/10\% FBS. When the cultures reached 70\% confluence, the cells were growth arrested for 48 hours with $0.5 \%$ FBS. The agonists, IL-8 (100 nM) and PDGF (10 ng/ $\mathrm{ml}$ ), were then added to the cultures. Forty-eight hours later, the cells were detached and counted on a haemacytometer.

\section{Data analysis}

Data are represented as mean \pm SEM unless otherwise indicated. Comparison of means was performed with Student-t tests. One-way ANOVA followed by Student's t-test was used for the chemotaxis assay. The empirical fre- quency distributions of the contractions of cells in response to IL- 8 were compared using a KolmogorovSmirnoff test. A difference was considered to be statistically significant when the $P$ value was less than 0.05 .

\section{Results}

Effects of IL-8 on contraction of ASM from CF individuals The length of the cells was measured before (Figure 1, panels $\mathrm{A}$ and $\mathrm{C}$ ) and at 10 minutes after the addition of IL8 (Figure 1, panels B and D) to CF and control cells respectively. Resting length was not significantly different between the two groups: CF: $2.84 \pm 0.25$ vs control: 2.26 \pm 0.29 arbitrary units $(\mathrm{p}=0.137)$. The effects of IL- 8 and PBS on the lengths of CF and non-CF cells are illustrated as cumulative frequency distributions (Figure 1E). IL-8 (100 nM) significantly decreased the length of the CF cells by $19 \pm 3 \%$ compared to $8 \pm 2 \%$ in control cells $(\mathrm{p}<0.05)$ whereas the changes in length of control and CF cells treated with vehicle $(1.5 \pm 1 \%$ and $3.7 \pm 3 \%$, respectively) did not differ significantly.

\section{Flow cytometric quantification of CXCRI and CXCR2}

The surface expression of CXCR1 and CXCR2 protein on ASM cells from both control and CF subjects was studied by flow cytometry. The results are presented as overlaid histograms and the percentages of positive cells were calculated by subtraction of isotype controls from antibody marked cells. Figure 2 shows illustrative results of flow cytometry for CF (panel A) and control cells (panel B) for CXCR1, and CF (panel C) and control cells (panel D) for CXCR2. Panel E shows summary data expressed as the \% of cells stained for CXCR 1 and CXCR2 in CF $(37 \pm 2 \%$ and $16 \pm 0.8 \%$, respectively) and control groups (34 $\pm 2 \%$ and $22 \pm 2 \%$, respectively). There are no significant differences in the expression of either CXCR1 or CXCR2 by control and CF ASM cells.

\section{Effects of IL-8 on $\left[\mathrm{Ca}^{2+}\right]_{i}$}

IL-8-induced $\mathrm{Ca}^{2+}$ transients were measured in cells from control and CF-affected individuals. Figure 3 a shows that IL-8 (100 nM) induced a rapid increase in the $\left[\mathrm{Ca}^{2+}\right]_{\mathrm{i}^{\prime}}$, which subsequently returned towards resting values. IL-8 increased the $\left[\mathrm{Ca}^{2+}\right]_{\mathrm{i}}$ to $228 \pm 7 \mathrm{nM}$ in control cells, significantly greater than the value of $198 \pm 10 \mathrm{nM}$ in CF cells $(\mathrm{p}<0.05$; Figure $3 \mathrm{~b})$. The resting $\left[\mathrm{Ca}^{2+}\right]_{\mathrm{i}}$ was $87 \pm 2 \mathrm{nM}$ in control cells and lower in CF cells $(72 \pm 2 \mathrm{nM}$; $\mathrm{p}<0.05)$.

\section{IL-8 induced phosphorylation of myosin light chain 20 (MLC $\left.\boldsymbol{C}_{\mathbf{2 0}}\right)$}

Western analysis was used to study the effects of IL-8 on the phosphorylation of $\mathrm{MLC}_{20}$ in CF and control cells. Figure 4 shows the extent of $\mathrm{MLC}_{20}$ phosphorylation in CF and control cells (panel A) under control conditions and after stimulation by IL- 8 for 1 and 5 minutes. In panel B, the densitometry results (mean \pm SEM) are expressed as 

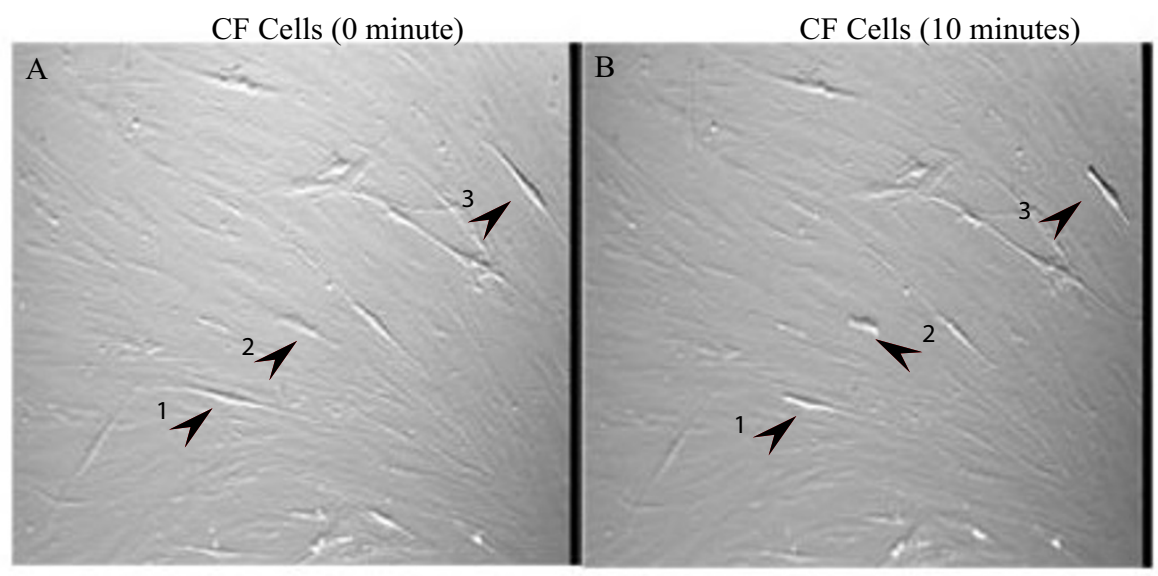

Normal Cells (0 minute)

Normal Cells (10 minutes)
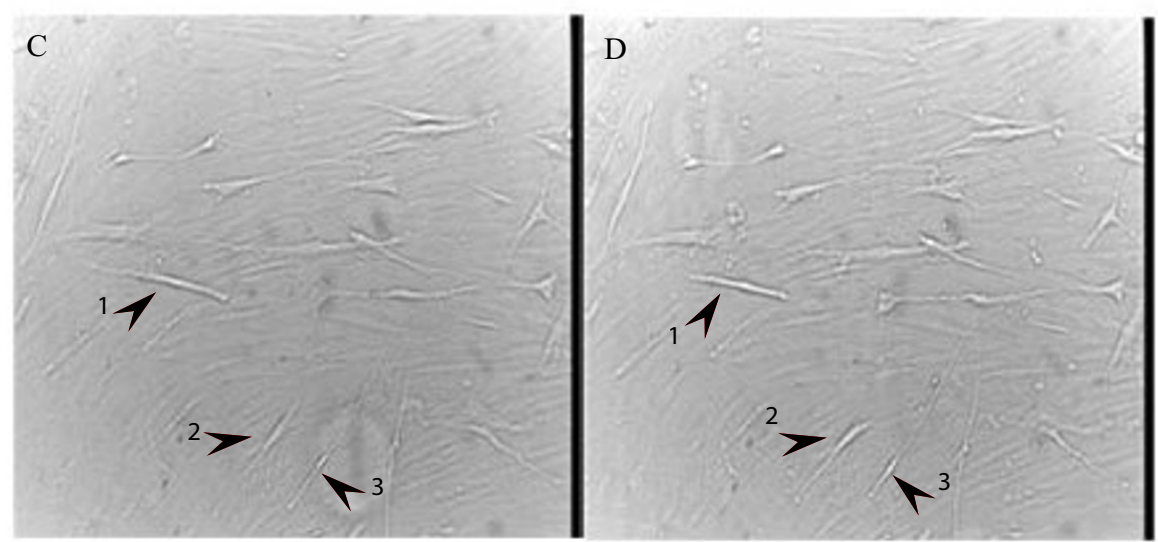

E

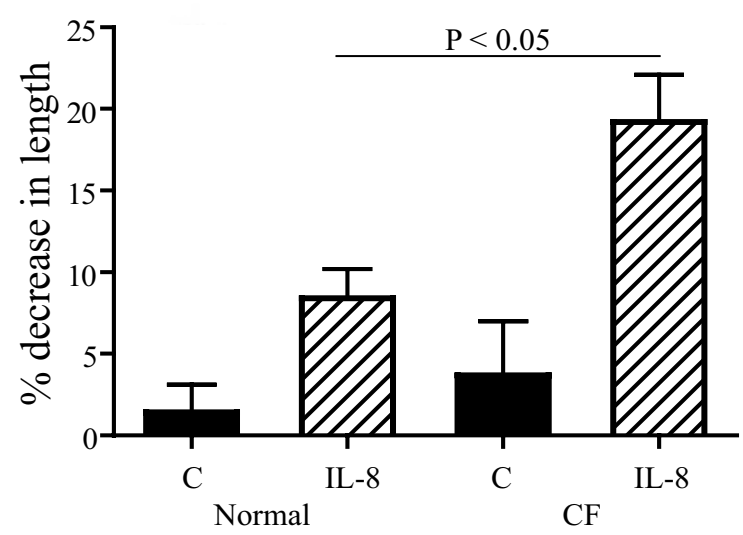

\section{Figure I}

Contraction of CF and control ASM cells treated with IL-8. Panels A and B show the images recorded before and I0 minutes after the addition of IL-8 (I00 nM) in CF cells. The cells that are clearly visualized are live cells and the indistinct cells are the background of alcohol-fixed cells that serve as a substratum. Arrows indicate the contracted cells. Panel $C$ and $D$ show the images of control cells before and after the addition of IL-8. Panel E represents the \% decrease in the CF and non-CF cell lengths (C) following IL-8 or PBS treatments. Cumulative frequency distributions are shown and the distributions were compared statistically using the Kolmogorov-Smirnoff test. The IL-8 treated CF cells shortened to a significantly greater degree than the non-CF cells ( $\mathrm{P}<0.05) .40 \mathrm{CF}$ cells and 36 control cells from four different individuals per group were measured. The values are expressed in \% decrease in the length of the cell following IL-8 stimulation. 
A

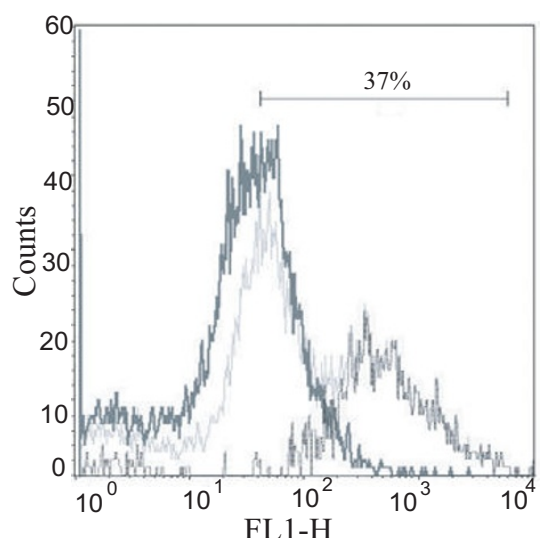

C

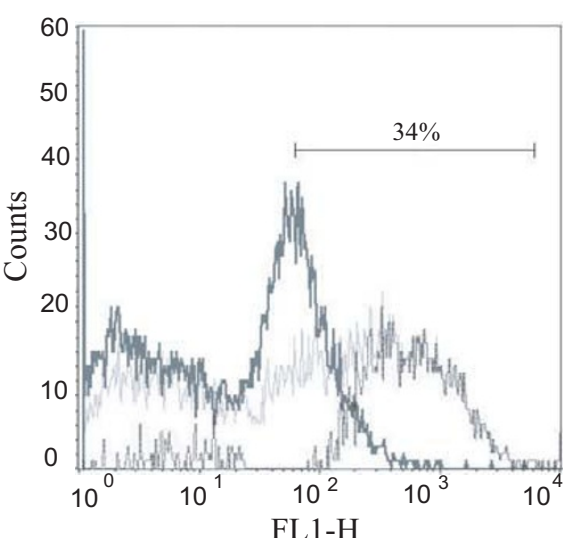

B

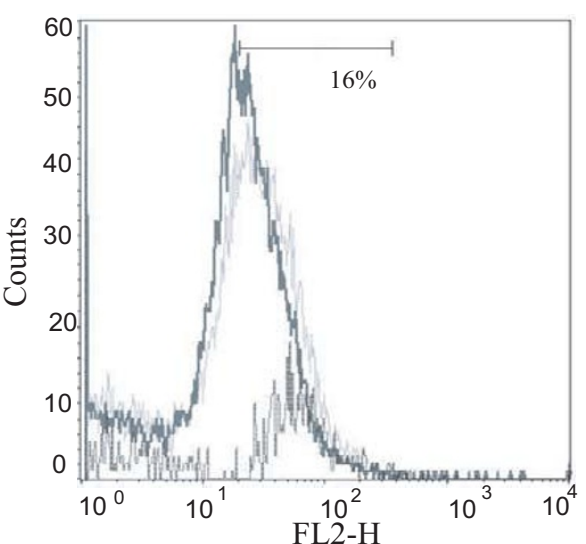

$\mathrm{D}$

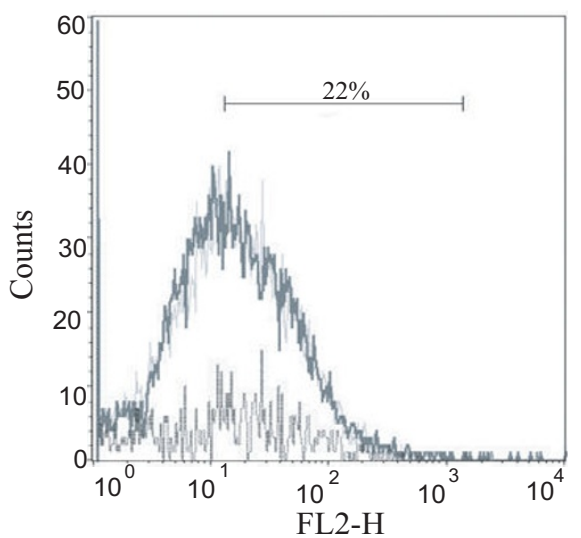

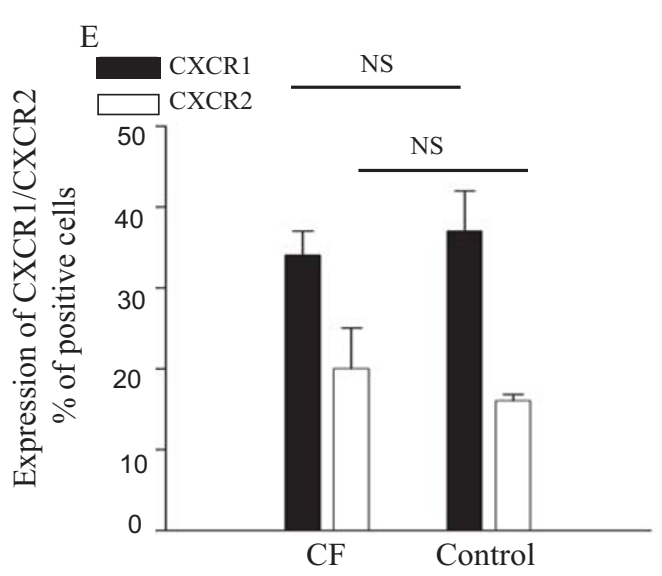

Figure 2

Flow cytometric analysis of the surface expression of CXCR-I and CXCR-2 on ASM cells from CF and control patients. Representative examples of the expression of CXCRI and CXCR2 from CF and control patients are shown in panels $2 A, 2 B, 2 C$ and $2 D$ respectively. The histogram outlined by the darkest lines represents the distribution of isotype control cells, the lightest shade represents the cells stained with specific antibody and the intermediate shade represents the difference between positively stained cells and isotype controls. Panel E shows the percentage of cells stained for CXCRI and CXCR2 from 4 different cell preparations of CF and control patients. 

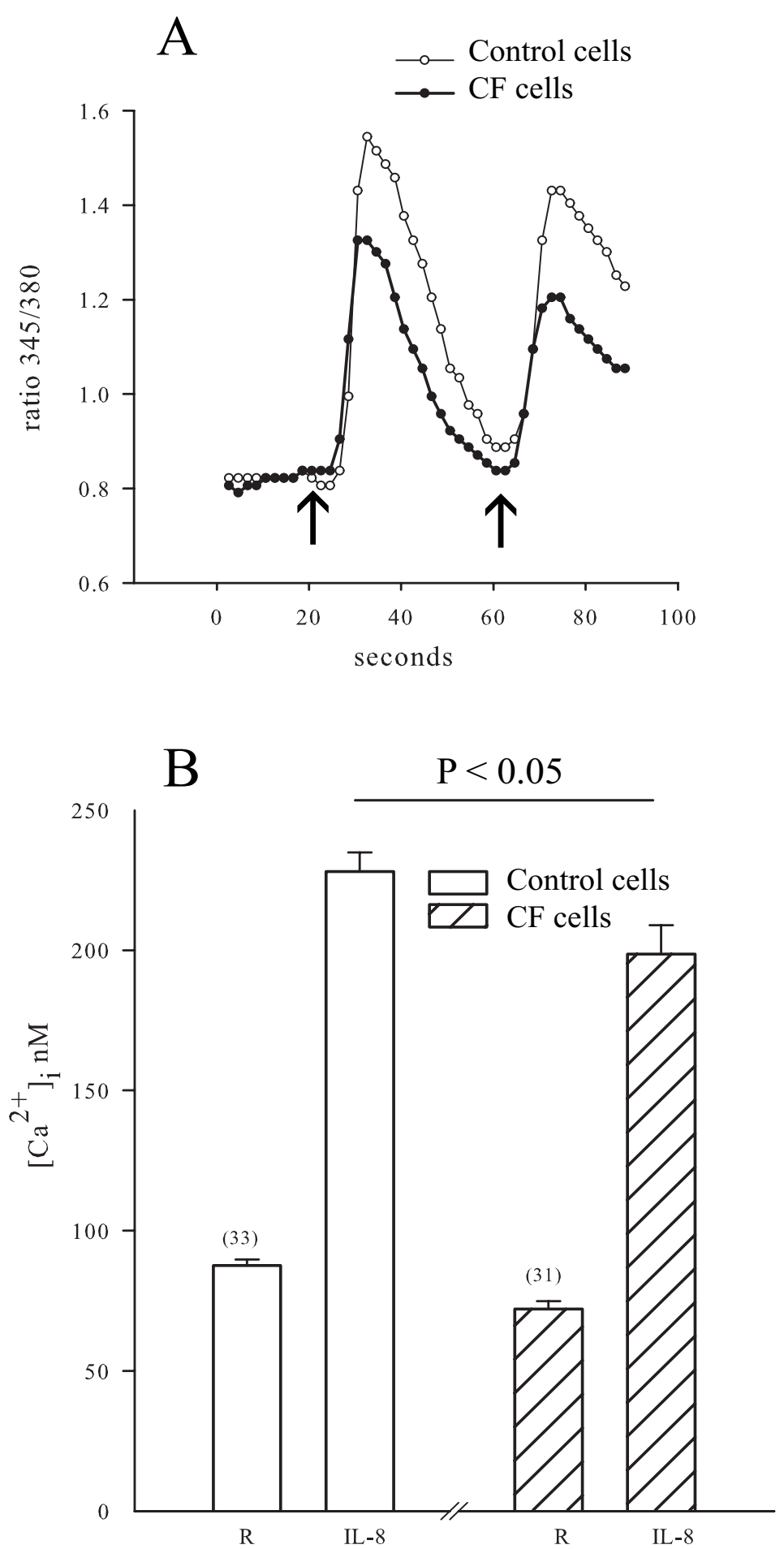

Figure 3

Effects of IL-8 on $\left[\mathrm{Ca}^{2+}\right]_{i}$ in CF and control cells. Cultured ASM cells from CF and control subjects were stimulated with IL-8 (I00 nM). Illustrative examples of responses of a control cell and a cell from a CF-affected subject are shown in panel I. The left hand arrow indicates the addition of IL- 8 to the medium and the right hand arrow represents the addition of histamine $(\mathrm{I} \mu \mathrm{M})$ to serve as a positive control. The resting $\left[\mathrm{Ca}^{2+}\right]_{\mathrm{i}}(\mathrm{R})$ and the peak $\left[\mathrm{Ca}^{2+}\right]_{\mathrm{i}}$ induced by IL-8 (IL-8) from the control (open bars) and the CF group (hatched bars) are shown. ( $n=48$ cells recorded on 6 different slides from 4 individuals in each group). 
A

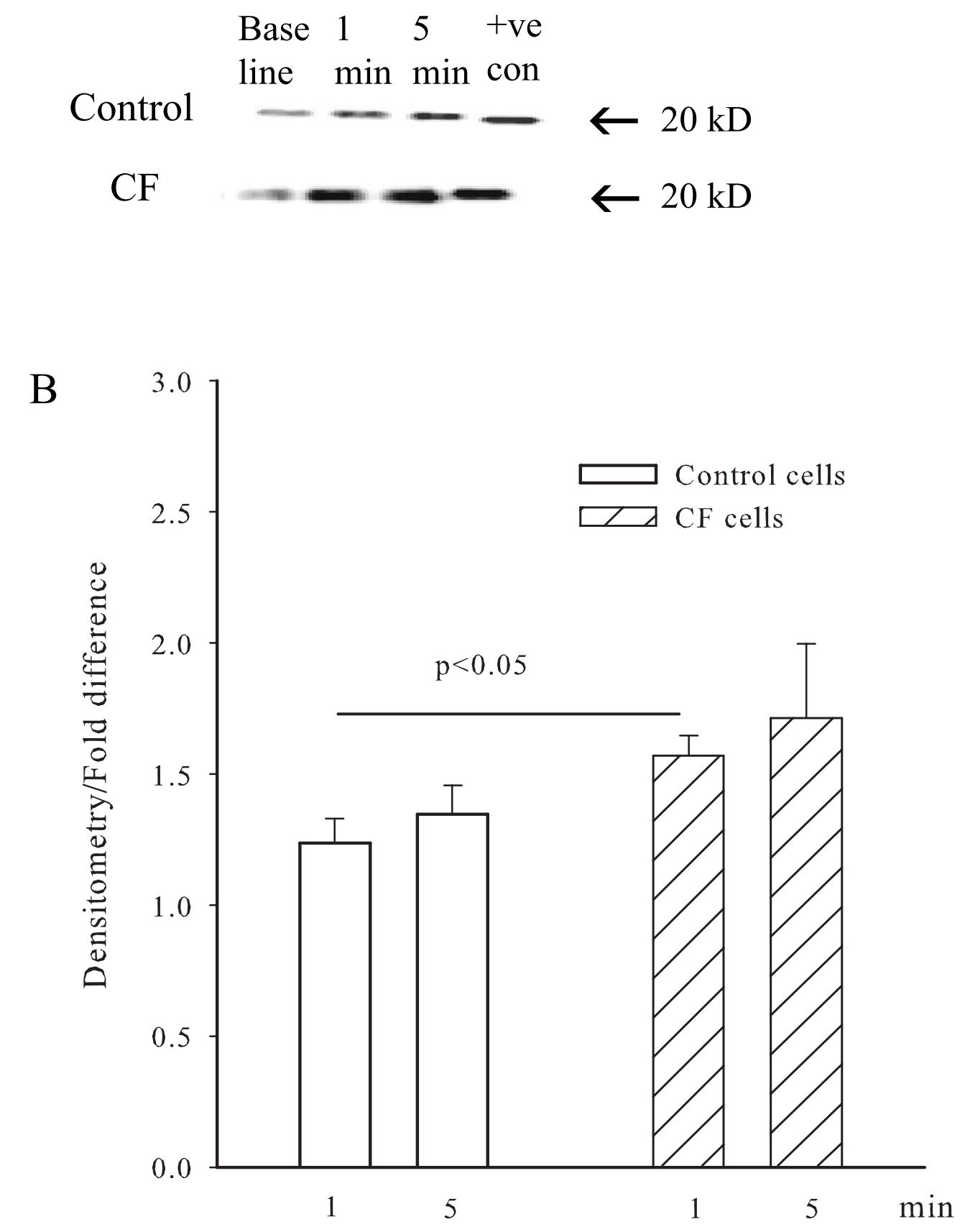

\section{Figure 4}

IL-8 induced phosphorylation of MLC $_{20}$ from CF and control cells. Panel A shows representative blots of myosin light chain $\left(\mathrm{MLC}_{20}\right)$ phosphorylation from CF and control cells. Bands correspond to baseline and IL-8 stimulation at I and 5 minutes. Thiophosphorylated myosin from chicken gizzard was used as a positive control (+ve con). Panel B shows the average increase in $\mathrm{MLC}_{20}$ phosphorylation (expressed as fold difference from baseline) in CF and control cells. The MLC 20 Phosphorylation from CF cells was significantly different from control cells at I minute after treatment with IL-8. 
the fold difference compared to baseline, the phosphorylation of $\mathrm{MLC}_{20}$ was increased at 1 minute after treatment with IL-8 consistent with activation of contractile signaling pathways and was significantly greater in CF cells (1.5 fold) than in control cells (1.2 fold). At 5 minutes, there was a further slight increase in phosphorylation, but the differences were not quite statistically significant between CF and control cells.

\section{Expression of myosin light chain ${ }_{20}$}

Proteins were extracted from unstimulated $\mathrm{CF}$ and control cells and the expression of total $\mathrm{MLC}_{20}$ was determined by immunoblotting. Figure 5A shows the Western blot analysis for the expression of $\mathrm{MLC}_{20}$ protein in CF and control cells. Quantitative assessment with densitometry shows that the content of $\mathrm{MLC}_{20}$ was higher (Figure $5 \mathrm{~B}, \mathrm{p}<0.05$ ) in CF (15.7 arbitrary units) than in control cells (5.7 arbitrary units).

\section{Effects of IL-8 on migration of cells}

A chemotaxis assay to IL-8 was performed and the results are shown in Figure 6 for the migration of CF and control cells in response to two concentrations of IL-8 (10 and $100 \mathrm{nM}$ ). The results are expressed as fold difference compared to vehicle treated cells. IL-8 stimulated the migration of both control and CF cells at concentrations of 10 $\mathrm{nM}$ and $100 \mathrm{nM}$ compared to vehicle-treated cells. However, there was no difference in the migration rates of the two groups of cells.

\section{Effects of II-8 on cellular proliferation}

Exposure to IL-8 evoked a modest proliferation of CF and control cells that was comparable in both groups: $132.0 \pm$ $9.5 \%$ for CF cells ( $\mathrm{n}=4$ independent experiments) and $123.2 \pm 14.5 \%(\mathrm{n}=5$ independent experiments) for control cells. PDGF was used as a positive control. It induced a robust proliferation (figure 7); the increase in cell proliferation following stimulation with PDGF was $190.8 \pm$ $9.8 \%$ for CF and $198.6 \pm 22.4 \%$ for control cells.

\section{Discussion}

The results of this study demonstrate that IL-8 induces a greater contraction of ASM cells from CF patients compared to those of control individuals. The augmentation of ASM contraction is associated with a greater degree of phosphorylation of $\mathrm{MLC}_{20}$ with IL- 8 and higher expression of $\mathrm{MLC}_{20}$ in CF cells. There was no difference in the expression of CXCRs between CF and control cells. Peak $\mathrm{Ca}^{2+}$ release induced by IL- 8 was decreased in CF ASM cells compared to control cells, an observation that was largely explained by a lower resting $\left[\mathrm{Ca}^{2+}\right]_{\mathrm{i}}$. A similar difference in $\mathrm{Ca}^{2+}$ regulation in response to histamine has been observed in tracheal gland cells and in nasal epithelial cells of CF patients but the reason for this abnormality was reported as unknown [29,30]. Despite these altera- tions, neither migration nor proliferation was significantly different between the two groups. These results indicate that CF cells are hypercontractile to IL-8, an effect that is not observed in the proliferative and migratory responses.

Chronic infection and inflammation leads to loss of more than one third of the epithelium from both central and peripheral airways of CF patients [9]. As a result, the ASM cells are exposed to various inflammatory mediators such as TNF- $\alpha$, IL-1 $\beta$ and IL- 8 . Cytokines such as TNF- $\alpha$, IL- $1 \beta$, IL-5 and IL-13 may modulate the contraction of ASM by indirect mechanisms through effects on cellular phenotype [31-33]. However chemokines such as IL-8 derived from inflammatory cells such as neutrophils [34], and perhaps from residual epithelial cells, may have direct effects on ASM as bronchonconstrictors because they act through G-protein coupled receptors linked to phospholipase C. Indeed IL-8 is a significant contractile agonist for human ASM cells [25]. In the current study we focused on IL-8 because of its importance for airway neutrophilic inflammation, which is a prominent feature of CF and is present also in some asthmatic subjects. The finding of the hypercontractile response to IL- 8 may therefore have significance for the regulation of airway tone in CF affected subjects.

We tested the possibility that altered signaling mechanisms could account for the enhancement of the contraction in response to IL- 8 by measuring the expression of CXCRs and the effects of IL- 8 on $\left[\mathrm{Ca}^{2+}\right]_{\mathrm{i}}$. Flow cytometry confirmed our previous report of CXCR 1 and 2 expression in control cells [25], albeit at a lower level than in neutrophils. Our current results demonstrated comparable levels of expression of CXCR1 and CXCR2 between CF and control cells. This finding is not unexpected, given that the increase in responsiveness of CF cells to IL- 8 was confined to its effect on the contraction whereas there were no differences in responsiveness as measured by migration and proliferation. We explored next the possibility that the enhanced ASM contraction in CF might be related to exaggerated increases in $\left[\mathrm{Ca}^{2+}\right]_{\mathrm{i}}$. Rather than the expected enhanced $\mathrm{Ca}^{2+}$ transients in CF cells, fluorescence imaging of intracellular $\mathrm{Ca}^{2+}$ showed that IL-8 evoked lower $\mathrm{Ca}^{2+}$ transients compared to control cells. Next, we explored other mechanisms for the increased contraction of CF ASM cells, namely $\mathrm{MLC}_{20}$ phosphorylation. Our data showed that there was a greater increase in $\mathrm{MLC}_{20}$ phosphorylation in the CF cells compared to controls. However the increase in $\mathrm{MLC}_{20}$ phosphorylation was modest and less than the magnitude of the increased expression of $\mathrm{MLC}_{20}$ measured in the CF cells. In addition to its role in contraction, IL-8 can also trigger ASM to respond by proliferation or migration [25]. However the increased response of CF cells to IL- 8 was not reproduced 

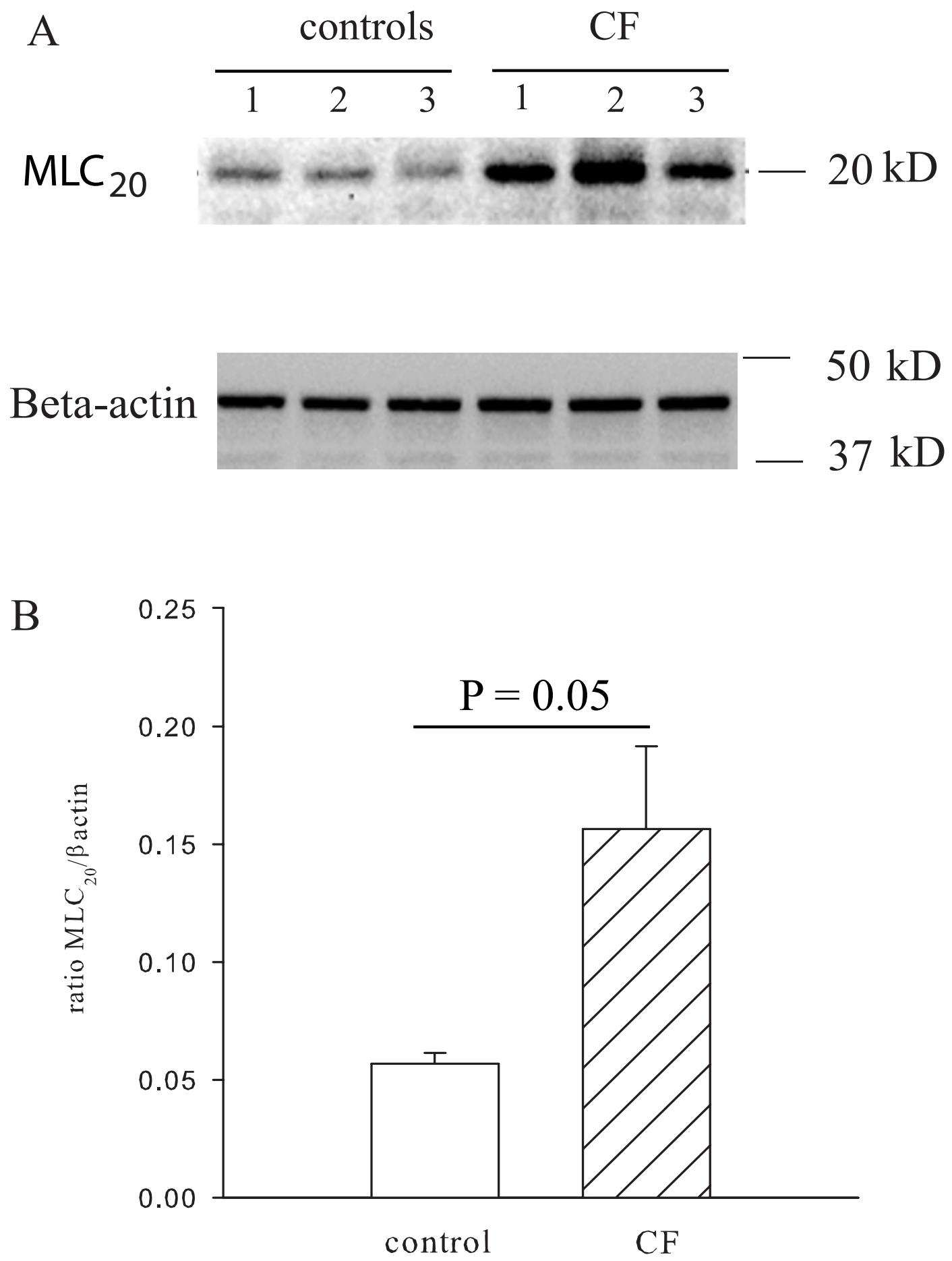

Figure 5

Expression of $\mathrm{MLC}_{20}$ in CF and control cells. Panel $A$ is a representative blot for the expression of $\mathrm{MLC}_{20}$ in CF and control cells. Panel B. Mean densitometric values of $M L_{20}$ expression (corrected to $\beta$-actin) in CF cells is higher than control cells $(n=4$ experiments). 


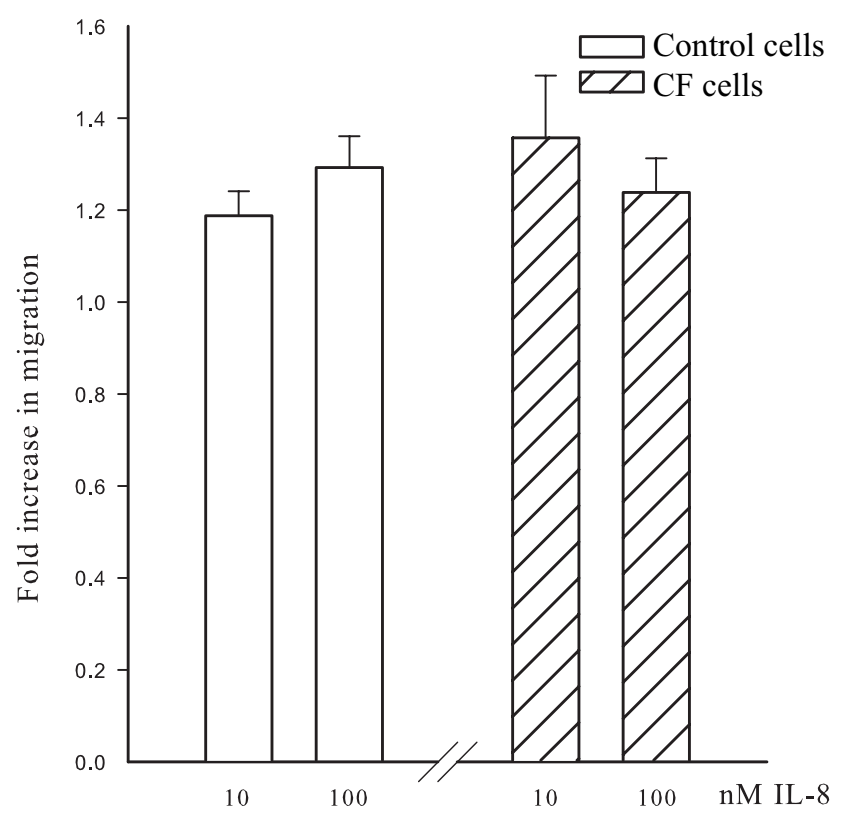

Figure 6

The effects of IL-8 on ASM cell migration in CF and control cells. Histogram illustrates the IL-8 induced migration of CF and control cells at concentrations of 10 and 100 nM. The data are represented as the fold difference compared to vehicle treated cells. There was no significant difference between CF and control cells.

in relationship to other cellular functions such as chemotaxis and proliferation. The mechanistic link between the CFTR channel and the contractile properties of airway smooth muscle has not been established. However, Robert et al have reported that CFTR channels are present in rat vascular smooth muscle cells and that stimulation of the channels by specific CFTR agonists produces relaxation of pre-contracted vascular tissue [36]. Data from our laboratory show that CFTR channels are present and have functional effects on calcium signaling in ASM cells [37].

In conclusion, our findings show that the ASM cells of cystic fibrosis patients are more contractile than those of control subjects to stimulation by IL-8. This enhanced contractility appears to be attributable to phenotypic differences and could be responsible, at least in part, for the airway hyperresponsiveness and asthmatic diathesis observed in many of these patients.

\section{Competing interests}

The authors declare that they have no competing interests.

\section{Authors' contributions}

VG participated in the design of the study, carried out many of the experiments and wrote the manuscript. MCM

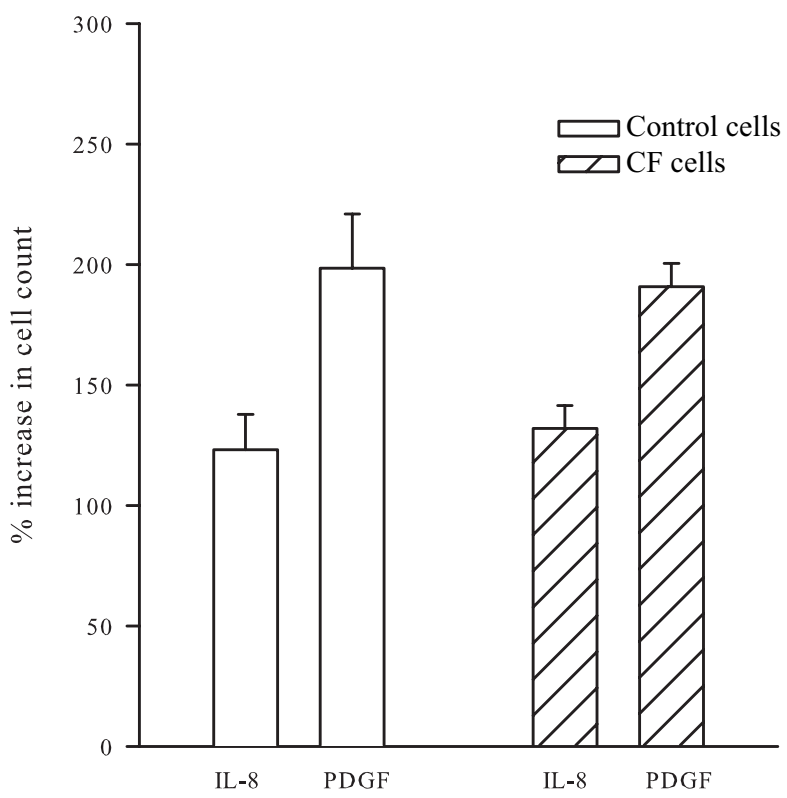

Figure 7

IL-8 induces cell proliferation in both CF and control cells. This figure shows the increase in cell counts measured with a haemocytometer (expressed as \% of baseline) in response to IL-8 $(100 \mathrm{nM})$ and PDGF $(10 \mathrm{ng} / \mathrm{ml})$ treatments. There was no significant difference between the CF and control cells.

established the cell culture and supervised the cell proliferation experiments. PF contributed to the cell culture. HVC carried out the western blot analysis, KS did the proliferation experiments. JA measured cell contraction. JGM conceived of the study, participated in its design and coordination, and helped to write the manuscript. All authors read and approved the final manuscript.

\section{Acknowledgements}

The study was supported by the Canadian Cystic Fibrosis Foundation

\section{References}

I. Riordan JR, Rommens JM, Kerem B, Alon N, Rozmahel R, Grzelczak Z, Zielenski J, Lok S, Plavsic N, Chou JL, Drumm ML, lanuzzi MC, Collins FS, Tsui L-C: Identification of the cystic fibrosis gene: cloning and characterization of complementary DNA. Science 1989, 245:1066-1073.

2. Smith AL, Ramsey B, Redding G, Haas J: Endobronchial infection in cystic fibrosis. Acta Paediatr Scand Suppl 1989, 363:31-36.

3. Armstrong DS, Grimwood K, Carzino R, Carlin JB, Olinsky A, Phelan PD: Lower respiratory infection and inflammation in infants with newly diagnosed cystic fibrosis. Brit Med J 1995, 310:157I-I572.

4. Khan TZ, Wagener JS, Bost T, Martinez J, Accurso FJ, Riches DW: Early pulmonary inflammation in infants with cystic fibrosis. Am J Respir Crit Care Med 1995, I 5 I: 1075- 1082.

5. Rosenfeld M, Gibson RL, McNamara S, Emerson J, Burns JL, Castile R, Hiatt P, McCoy K, Wilson CB, Inglis A, Smith A, Martin TR, Ramsey $B W$ : Early pulmonary infection, inflammation, and clinical outcomes in infants with cystic fibrosis. Pediatr Pulmonol 200 I, 32:356-366 
6. Boucher RC: Human airway ion transport. Part one. Am / Respir Crit Care Med 1994, I50:27I-28I.

7. Mitchell I, Corey M, Woenne R, Krastins IR, Levison H: Bronchial hyperreactivity in cystic fibrosis and asthma. J Pediatr 1978, 93:744-748.

8. Mellis CM, Levison H: Bronchial reactivity in cystic fibrosis. Pediatrics 1978, 61:446-450.

9. Tiddens HA, Koopman LP, Lambert RK, Elliott WM, Hop WC, Mark TW van der, de Boer WJ, de Jongste JC: Cartilaginous airway wall dimensions and airway resistance in cystic fibrosis lungs. Eur Respir J 2000, 15:735-742.

10. Ormerod LP, Thomson RA, Anderson CM, Stableforth DE: Reversible airway obstruction in cystic fibrosis. Thorax 1980, 35:768-772.

II. van Haren EH, Lammers JW, Festen J, van Herwaarden CL: Bronchial vagal tone and responsiveness to histamine, exercise and bronchodilators in adult patients with cystic fibrosis. Eur Respir J 1992, 5: 1083-1088.

12. Avital A, Sanchez I, Chernick V: Efficacy of salbutamol and ipratropium bromide in decreasing bronchial hyperreactivity in children with cystic fibrosis. Pediatr Pulmonol 1992, 13:34-37.

13. Sagel SD, Accurso FJ: Monitoring inflammation in CF. Cytokines. Clin Rev Allergy Immunol 2002, 23:4I-57.

14. Nakamura H, Yoshimura K, McElvaney NG, Crystal RG: Neutrophil elastase in respiratory epithelial lining fluid of individuals with cystic fibrosis induces interleukin-8 gene expression in a human bronchial epithelial cell line. J Clin Invest 1992, 89:|478-|484

15. Richman-Eisenstat JB, Jorens PG, Hebert CA, Ueki I, Nadel JA: Interleukin-8: an important chemoattractant in sputum of patients with chronic inflammatory airway diseases. $\mathrm{Am} J$ Physiol I003, 264(4 Pt. I):L4I3-L4I8.

16. Tabary O, Zahm JM, Hinnrasky J, Couetil JP, Cornillet P, Guenounou $M$, Gaillard D, Puchelle E, Jacquot J: Selective up-regulation of chemokine IL-8 expression in cystic fibrosis bronchial gland cells in vivo and in vitro. Am J Pathol 1998, I 53:921-930.

17. Konstan MW, Berger M: Current understanding of the inflammatory process in cystic fibrosis: onset and etiology. Pediatr Pulmonol 1997, 24:137-142.

18. Holmes WE, Lee J, Kuang WJ, Rice GC, Wood WI: Structure and functional expression of a human interleukin-8 receptor. Science |99|, 253: |278-1280.

19. Bacon KB, Westwick J, Camp RD: Potent and specific inhibition of IL-8-, IL-I alpha- and IL-I beta-induced in vitro human lymphocyte migration by calcium channel antagonists. Biochem Biophys Res Commun 1989, 165:349-354.

20. Leonard EJ, Skeel A, Yoshimura T, Noer K, Kutvirt S, Van Epps D: Leukocyte specificity and binding of human neutrophil attractant/activation protein-I. J Immunol 1990, I44:I323-I330.

21. Wang JM, Walter S, Mantovani A: Re-evaluation of the chemotactic activity of tumour necrosis factor for monocytes. Immunology 1990, 71:364-367.

22. Yue TL, Wang X, Sung CP, Olson B, McKenna PJ, Gu JL, Feuerstein GZ: Interleukin-8. A mitogen and chemoattractant for vascular smooth muscle cells. Circ Res 1994, 75:1-7.

23. Yue TL, McKenna PJ, Gu JL, Feuerstein GZ: Interleukin-8 is chemotactic for vascular smooth muscle cells. Eur J Pharmacol 1993, 240:8I-84

24. Fujimura M, Myou S, Nomura M, Mizuguchi M, Matsuda T, Harada A, Mukaida N, Matsushima K, Nonomura A: Interleukin-8 inhalation directly provokes bronchoconstriction in guinea pigs. Allergy 1999, 54:386-391.

25. Govindaraju V, Michoud M-C, Al-Chalabi M, Ferraro P, Powell WS, Martin JG: Interleukin-8: novel roles in human airway smooth muscle cell contraction and migration. Am J Physiol Cell Physiol 2006, 291 (5):C957-65.

26. Randell SH, Walstad L, Schwab UE, Grubb BR, Yankaskas JR: Isolation and culture of airway epithelial cells from chronically infected human lungs. In Vitro Cell Dev Biol Anim 200 I, 37:480-489.

27. Govindaraju V, Martin JG, Maghni K, Ferraro P, Michoud MC: The effects of extracellular purines and pyrimidines on human airway smooth muscle cells. J Pharmacol Exp Ther 2005, 315:941-948.

28. Tao F, Chaudry S, Tolloczko B, Martin JG, Kelly SM: Modulation of smooth muscle phenotype in vitro by homologous cell substrate. Am J Physiol Cell Physiol 2003, 284:CI53I-CI54I.
29. Reinlib L, Jefferson DJ, Marini FC, Donowitz M: Abnormal secretagogue-induced intracellular free $\mathrm{Ca2}+$ regulation in cystic fibrosis nasal epithelial cells. Proc Natl Acad Sci USA 1992, 89:2955-2959.

30. Jacquot J, Maizieres M, Spilmont C, Millot JM, Sebille S, Merten M, Kammouni W, Manfait M: Intracellular free Ca2+ dynamic changes to histamine are reduced in cystic fibrosis human tracheal gland cells. FEBS Lett 1996, 386:123-127.

31. Ammit AJ, Lazaar AL, Irani C, O'Neill GM, Gordon ND, Amrani Y, Penn RB, Panettieri RA Jr: Tumor necrosis factor-alpha-induced secretion of RANTES and interleukin-6 from human airway smooth muscle cells: modulation by glucocorticoids and beta-agonists. Am J Respir Cell Mol Biol 2002, 26:465-474

32. Rizzo CA, Yang R, Greenfeder S, Egan RW, Pauwels RA, Hey JA: The IL-5 receptor on human bronchus selectively primes for hyperresponsiveness. J Allergy Clin Immunol 2002, 109:404-409.

33. Grunstein $M M$, Hakonarson $H$, Leiter J, Chen $M$, Whelan $R$, Grunstein JS, Chuang S: IL-I3-dependent autocrine signaling mediates altered responsiveness of IgE-sensitized airway smooth muscle. Am J Physiol Lung Cell Mol Physiol 2002, 282:L520-L528.

34. Wertheim WA, Kunkel SL, Standiford TJ, Burdick MD, Becker FS, Wilke CA, Gilbert AR, Strieter RM: Regulation of neutrophilderived IL-8: the role of prostaglandin E2, dexamethasone, and IL-4. J Immunol I 5 I (4):2 I66-75. I993 Aug I5

35. Mukhina S, Stepanova V, Traktouev D, Poliakov A, Beabealashvilly R, Gursky Y, Minashkin M, Shevelev A, Tkachuk V: The chemotactic action of urokinase on smooth muscle cells is dependent on its kringle domain. Characterization of interactions and contribution to chemotaxis. J Biol Chem 2000, 275:16450-16458.

36. Robert R, Thoreau V, Norez C, Cantereau A, Kitzis A, Mettey Y, Rogier C, Becq F: Regulation of the cystic fibrosis transmembrane conductance regulator channel by beta-adrenergic agonists and vasoactive intestinal peptide in rat smooth muscle cells and its role in vasorelaxation. J Biol Chem 2004, 279:2II60-2II68.

37. Michoud MC, Robert R, Hassan M, Moynihan B, Haston C Govindaraju V, Ferraro P, Hanrahan JW, Martin JG: Role of the CFTR Channel in Human Airway Smooth Muscle. Am J Respir Cell Mol Biol in press. 2008 Aug 28

\section{Publish with BioMed Central and every scientist can read your work free of charge}

"BioMed Central will be the most significant development for disseminating the results of biomedical research in our lifetime. "

Sir Paul Nurse, Cancer Research UK

Your research papers will be:

- available free of charge to the entire biomedical community

- peer reviewed and published immediately upon acceptance

- cited in PubMed and archived on PubMed Central

- yours - you keep the copyright
BioMedcentral 